\title{
Aspen Recovery Since Wolf Reintroduction on the Northern Yellowstone Winter Range
}

\author{
David S. Kimble, ${ }^{1}$ Daniel B. Tyers, ${ }^{2}$ Jim Robison-Cox, ${ }^{3}$ and Bok F. Sowell ${ }^{4}$ \\ Authors are ${ }^{1}$ US Fish and Wildife Service, Evanston, WY 82930, USA; ${ }^{2}$ USDA Forest Service, Bozeman, MT 59715, USA; ${ }^{3}$ Department of Mathematics, \\ Montana State University, Bozeman, MT 59717, USA; and ${ }^{4}$ Department of Animal and Range Sciences, Montana State University, Bozeman,
} MT 59717, USA.

\begin{abstract}
Quaking aspen (Populus tremuloides Michx.) recruitment and overstory stem densities were sampled in 315 clones in 1991 and 2006 on $560 \mathrm{~km}^{2}$ of the Northern Yellowstone Winter Range (NYWR). A primary objective was to observe if aspen status had improved from 1991 to 2006: evidence of a wolf (Canis lupus) caused trophic cascade. Recruitment stems (height $>2 \mathrm{~m}$ and diameter at breast height $<5 \mathrm{~cm}$ ) represent recent growth of aspen sprouts above elk (Cervus elaphus) browsing height, whereas overstory stems (all stems $>2 \mathrm{~m}$ ) represent the cohort of stems, which will insure the sustainability of the clone. Overstory stem densities declined by $12 \%(P=0.04)$ on the landscape scale when compared with paired t-tests. Overstory stems declined in $58 \%$ of individual clones and in $63 \%$ of the 24 drainages of the study area. The second objective was to determine which factors influenced changes in aspen density. Winter ungulate browsing $(P=0.0001)$, conifer establishment $(P=0.0001)$, and cattle (Bos spp.) grazing $(P=0.016)$ contributed to the decline in overstory stem densities when analyzed using a mixed effects model of log transformed medians. Eighty percent of the clones were classified as having medium to high browsing levels in 1991, whereas $65 \%$ of the clones received a similar rating in 2006 , possibly due to the reduced NYWR elk population. Aspen recruitment has increased in some $2-10 \mathrm{~km}^{2}$ areas, but not consistently. Our study found that a trophic cascade of wolves, elk, and aspen, resulting in a landscape-level recovery of aspen, is not occurring at this time.
\end{abstract}

\section{Resumen}

Se muestreó el reclutamiento y la densidad de tallos aéreos de Populus tremuloides Michx. de 315 clones en 1991 y 2006 en un área de $560 \mathrm{~km}^{2}$ en la Invernada Norte de Yellowstone (NYWR). Un objetivo primario de este estudio fue observar si el estatus de P. tremuloides mejoró entre 1991 y 2006 evidenciando una cascada trófica causada por el lobo (Canis lupus). El reclutamiento de tallos nuevos (altura $>2 \mathrm{~m}$ y diámetro a la altura del pecho $<5 \mathrm{~cm}$ ) representa crecimiento de brotes recientes por encima de la línea de ramoneo de los ciervos (Cervus elaphus), mientras que los tallos aéreos (todos $\operatorname{los}$ tallos $>2 \mathrm{~m}$ ) representan la cohorte de tallos que asegurarán la sustentabilidad del clon. Las densidades de tallos aéreos decreció en un $12 \%$ $(P=0.04)$ a la escala de paisaje según una comparación realizada con un prueba de " $\mathrm{t}$ " apareada. Los tallos aéreos decrecieron en un $58 \%$ de los clones individuales y en un $63 \%$ de las 24 micro-cuencas del área de estudio. El segundo objetivo de este estudio fue determinar cuáles factores influenciaron los cambios en la densidad de $P$. tremuloides. El ramoneo invernal de los ungulados $(P=0.0001)$, el establecimiento de coníferas $(P=0.0001)$, y el pastoreo bovino (Bos spp.; $P=0.016)$ contribuyeron a la disminución en la densidad de tallos aéreos según un análisis de efectos mixtos utilizando una transformación logarítmica de las medianas. El 80\% de los clones fueron clasificados en la categoría de nivel de uso medio a elevado en 1991, mientras que el $65 \%$ de los clones recibieron una valoración similar en el 2006, posiblemente debido a la reducción en la población de ciervos en el NYWR. El reclutamiento de P. tremuloides ha aumentado en dos áreas de $10 \mathrm{~km}^{2}$, pero no de modo consistente. Nuestro estudio demostró que una cascada trófica de lobos, ciervos, y $P$. tremuloides, que resulte en una recuperación de esta especie leñosa a escala de paisaje, no está ocurriendo en este momento.

Key Words: browse, Cervus elaphus, elk, Populus tremuloides, recruitment, trophic cascade

\section{INTRODUCTION}

Quaking aspen (Populus tremuloides Michx.) habitats make up a small percentage of vegetative cover in the Rocky Mountains but commonly support more species and greater numbers of wildlife than associated conifer habitats (Debyle 1985a). Aspen

\footnotetext{
Funding or support for this research was provided by the USDA Forest Service and Montana State University. Gerry Bennett, Dick Ohman, and Jim Wood have also contributed significantly to wildlife and habitat research funding on the Gardiner Ranger District.

At the time of this research, Kimble was a MS candidate, Animal and Range Science Dept, Montana State University, Bozeman, MT 59717, USA.

Correspondence: David Kimble, US Fish \& Wildlife Service, Evanston, WY 82930, USA. Email: david_kimble@fws.gov

Manuscript received 27 January 2010; manuscript accepted 9 December 2010.
}

are clonal and primarily rely on root sprouts to replace aging stems for the species to persist in the Rocky Mountains (McDonough 1985). Disturbances that remove aspen overstory stimulate root sprouting (Frey et al. 2003), although sprouting will frequently occur without disturbance in the Yellowstone area (Kay 1990). Wild ungulates such as moose (Alces alces), Rocky Mountain elk (Cervus elaphus), and deer (Odocoileus spp.) selectively browse aspen suckers in winter because they are a palatable protein source that is often available above the snow (Houston 1982). Where ungulate densities are high, browsing can suppress aspen sucker growth and prevent aspen clones from replacing older overstory stems with younger stems (Debyle 1985b), even after disturbances that stimulate dense suckering (Bartos et al. 1994). 

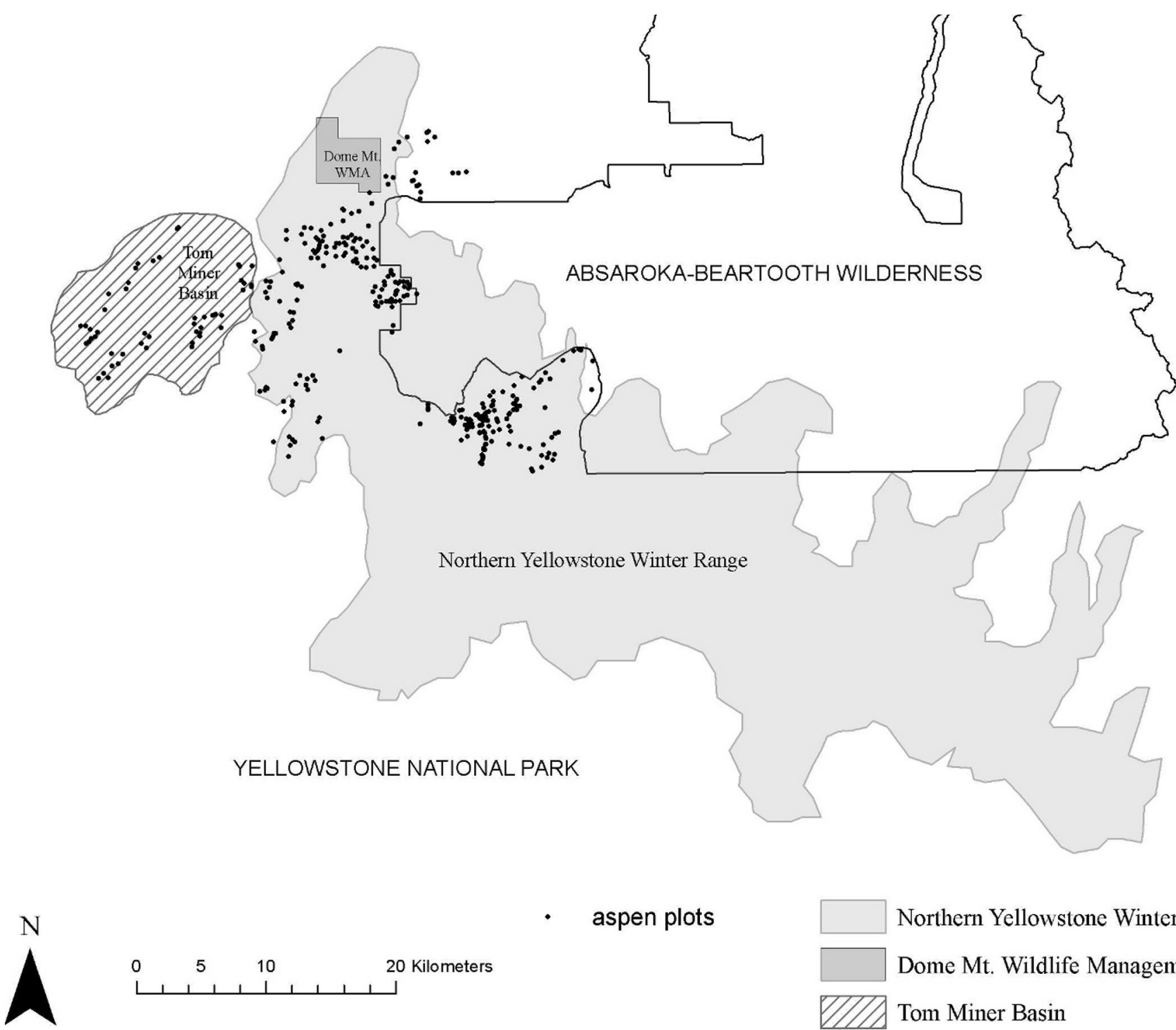

- aspen plots

Northern Yellowstone Winter Range

Dome Mt. Wildlife Management Area

Tom Miner Basin

Figure 1. Sampled aspen clone $(n=341)$ locations on the Gallatin National Forest, Montana.

Aspen coverage on the Northern Yellowstone Winter Range (NYWR) has declined from $4 \%$ to $10 \%$ of the landscape near the beginning of the 20th century to $1 \%$ presently (Wagner 2006). The NYWR is the wintering ground for Yellowstone National Park's (YNP) largest elk herd and consists of low- to mid-elevation areas in the Lamar, Yellowstone, and Gardner River drainages inside and outside YNP (Houston 1982; Fig. 1). Other factors such as a warmer and drier climate and fire suppression may play a role in aspen decline (YNP 1997). However, periods of drought have apparently not historically affected aspen regeneration elsewhere in the Greater Yellowstone Ecosystem (GYE; Hessl and Graumlich 2002), while warmer temperatures are associated with increased aspen growth in the GYE (Brown et al. 2006). Recent fires have not successfully regenerated aspen on the NYWR (Romme et al. 1995). Aspen sapling density is progressively lower and browse utilization is progressively higher on winter ranges with low, moderate, and high elk densities (White et al. 2003). Evidence suggests the primary immediate cause of aspen decline on the NYWR is browsing of suckers by wintering elk (National Research Council [NRC] 2002). St. John (1995) completed the largest study of its kind on the NYWR when he surveyed aspen clones on the Gallatin National Forest in 1991. He found that $47 \%$ of aspen clones $(n=342)$ had recently grown at least one sucker above elk-browsing height, but only $21 \%$ of clones had sufficient numbers of suckers escaping browsing for the overstories to remain stable or increase in density. Browsing by elk and cattle (Bos spp.) was a major factor preventing recruitment of new stems into the aspen overstory.

Wolves, a major predator of elk, were reintroduced into YNP in 1995 and quickly colonized much of the available habitat (Smith et al. 2005). The NYWR elk herd decreased 50\% from 1995 to 2005 (Northern Yellowstone Cooperative Wildlife Working Group [NYCWWG] 2005). Also, elk behavior changed in areas colonized by wolves (Laundre et al. 2001; Fortin et al. 2005; Mao et al. 2005). Some researchers 
hypothesized that wolf predation could relieve elk browsing pressure such that aspen overstories could regenerate-a trophic cascade (Ripple and Larsen 2000). Two means by which wolves could reduce elk browsing on aspen are direct reduction of the elk population or changes in elk behavior that decrease the quantity of aspen in their diet.

Several studies in YNP have sought to demonstrate that a reduction in elk browsing due to the presence of wolves may have resulted in a widespread increase in tall, palatable woody browse plants (Ripple and Beschta 2003, 2004, 2006, 2007; Beyer et al. 2007). Aspen (Ripple et al. 2001; Ripple and Beschta 2007), willow (Salix spp.; Ripple and Beschta 2004, 2006; Beyer et al. 2007), and cottonwood (Populus spp.; Ripple and Beschta 2003) have increased their growth since wolf reintroduction in some areas, primarily in riparian habitats. Some have suggested that elk are avoiding sites such as riparian areas where risk of wolf predation is high, thereby reducing elk browsing of willows at these sites (Ripple and Beschta 2006; Beyer et al. 2007). For example, browsing intensity has decreased and height of the tallest cohort of suckers in riparian aspen clones has increased in recent years in the Lamar Valley of the NYWR (Ripple and Beschta 2007). However, individual elk in similar riparian habitats on the Gallatin winter range consumed more willow when wolves were present than when wolves were absent (Creel and Christianson 2009). Kauffman et al. (2010) examined 16 aspen clones on the NYWR inside YNP and observed that elk browsing impacts on aspen were not reduced where risk of wolf predation was higher. Kauffman et al. (2010) and Creel and Christiansons' (2009) results call into question whether individual elk are consistently changing their behavior to browse woody plants less frequently, while the possibility that direct reduction of the elk population could improve browse plant regeneration has not been adequately examined. Kauffman et al. (2010) documented no recent increase in aspen stem growth above $2 \mathrm{~m}$, but only 16 clones were sampled. Other published studies have not addressed meaningful browse plant recovery on the NYWR because they are spatially limited (Ripple and Beschta 2003, 2004, 2006, 2007) or do not examine metrics for recruitment of plants above elk browsing height (Ripple et al. 2001; Beyer et al. 2007).

Aspen status in and around Rocky Mountain National Park, Colorado $\left(\approx 1500 \mathrm{~km}^{2}\right.$ area), was not adequately described by aspen status in Estes Valley within the Park $\left(\approx 10 \mathrm{~km}^{2}\right.$ area; Suzuki et al. 1999). Age structure and evidence of browsing differed in aspen clones where elk habitat use differed in the Jackson Hole, Wyoming, area $\left(\approx 400 \mathrm{~km}^{2}\right.$; Hessl and Graumlich 2002). Similarly, aspen status at a few specific sites inside YNP may not adequately describe the status of aspen on the NYWR. To date, published studies have not sufficiently addressed changes in broad-scale aspen overstory regeneration on the NYWR since wolf reintroduction. We hypothesized that aspen status in different subareas within our study area could not be extrapolated to the entire landscape. This study repeated the 1991 aspen survey on the Gallatin National Forest (St. John 1995). Objectives were: 1) to determine if aspen recruitment and overstory stem densities in the study area changed from 1991 to 2006; and 2) elucidate the factors that influence these changes.

\section{METHODS}

\section{Study Area}

The study area is in south-central Montana, primarily on the west unit of the Gardiner Ranger District, Gallatin National Forest and exclusive of the Absaroka-Beartooth Wilderness (Fig. 1). The southernmost portion of the study area abuts YNP. Mean annual precipitation in the Gardiner Basin at the southern end of the study area is $25 \mathrm{~cm}$. Mean minimum temperature in January is $-10^{\circ} \mathrm{C}$ and mean maximum temperature in July is $30^{\circ} \mathrm{C}$. Elevation in the town of Gardiner is $1618 \mathrm{~m}$. Average precipitation increases and temperature decreases as elevation increases in the study area. Elevation in Jardine, Montana, is $1966 \mathrm{~m}$ and mean annual precipitation is $45 \mathrm{~cm}$ (Western Regional Climate Center 2007). Vegetation primarily consists of big sagebrush (Artemisia tridentata subsp. Nutt) and grassland (e.g., Pseudoroegnaria spicata Pursh; Festuca idahoensis Elmer) at lower elevations, some quaking aspen at forest-grassland boundaries and in riparian areas, Douglas-fir (Pseudotsuga menziesii Franco) at mid-elevations, and lodgepole pine (Pinus contorta Douglas), Engelmann spruce (Picea engelmannii Parry), and subalpine fir (Abies lasiocarpa Hook.) at higher elevations (Despain et al. 1986). Aspen forests range from $1571 \mathrm{~m}$ to $2605 \mathrm{~m}$ in elevation and occupy $\approx 745$ ha of the $\approx 560 \mathrm{~km}^{2}$ study area (St. John 1995 ). Our study area was divided into 24 approximately $2-10 \mathrm{~km}^{2}$ hydrologic drainages that contained aspen.

Our study area includes most of the $40 \%$ of the NYWR that is outside YNP, but excludes private and state-owned land. Large numbers of elk winter on the state-owned Dome Mountain Wildlife Management Area north of YNP. Average wintering elk numbers on the Gallatin National Forest portion of the NYWR in 2000-2005 were about $45 \%$ less than in 1989-1999 (NYCWWG 2005). For comparison, average wintering elk numbers on the NYWR inside YNP declined $20 \%$ during the same time period (NYCWWG 2005; Vucetich et al. 2005). The greater proportional decline in wintering elk numbers on the Gallatin National Forest, our study area, was due in large part to an increasing proportion of elk wintering on the Dome Mountain Wildlife Management Area (NYCWWG 2005).

Wolves have colonized parts of the NYWR outside YNP, but at lower densities than inside YNP. Average wolf density during 2000-2005 was 0.054 wolves $\cdot \mathrm{km}^{-2}$ on our study area and 0.085 wolves $\cdot \mathrm{km}^{-2}$ on the NYWR inside YNP (US Fish and Wildlife Service [USFWS] et al. 2001, 2002, 2003, 2004, 2005, 2006). Twenty-five percent of our study area is Tom Miner Basin, not part of the NYWR. Like the rest of our study area, Tom Miner Basin is mostly winter range occupied by elk that are subject to wolf predation. Average winter elk counts in Tom Miner Basin declined about 35\% from the 1990s to 20002005 (Tom Lemke, unpublished data, 2006).

Cattle grazing on Forest Service allotments on our study area has declined throughout the past 20-30 yr. In the 1970s, 3621 animal unit months (AUMs) were grazed by cattle in 14 allotments on the Gardiner Ranger District (GRD). By 1995, 2867 AUMs were grazed by cattle on 11 allotments (St. John 1995). In 2006, six cattle allotments on the GRD were in use and 1788 AUMs were grazed (Gardiner Ranger District, unpublished data, 2006). 


\section{Sampling Methods}

Using a combination of marked topographical maps and photographic slides from 1991, aspen clones that St. John (1995) sampled were revisited (Fig. 1). Sampling methods were nearly identical to those employed by St. John (1995). After the aspen clone was relocated, the center of a $202.3 \mathrm{~m}^{2}$ (onetwentieth acre) circular plot was staked within the clone. The location of the plot within the clone depended upon, in ranking order: 1) where it appeared St. John's plot was located according to the photographic slide from 1991; 2) St. John's site description and site determinants such as slope, aspect, species of vegetation, or number of mature aspen stems within the plot; and 3) the location most representative of the aspen clone.

Live aspen stems $>2 \mathrm{~m}$ tall within the plot were counted and categorized as recruitment stems $(>2 \mathrm{~m}$ tall and $<5 \mathrm{~cm}$ diameter at breast height $[\mathrm{dbh}])$ or mature stems $(>2 \mathrm{~m}$ tall and $>5 \mathrm{~cm} \mathrm{dbh}$. Stems were categorized by height to determine if the terminal leader had grown above the reach of browsing elk. Stems $>2 \mathrm{~m}$ tall have grown beyond the height at which most elk browse the terminal leader (Kay 1985). Stems $>2 \mathrm{~m}$ tall and $<5 \mathrm{~cm}$ dbh theoretically have attained this height in recent years, while stems $>5 \mathrm{~cm}$ dbh represent earlier periods of recruitment in the clone (Kay 1985). Not all recruitment stems will necessarily survive as a long-term component of the aspen overstory, especially where elk populations are high (Keigley and Frisina 2005). Nevertheless, this fact does not invalidate the use of recruitment stems as an index. Even if only a fraction of recruitment stems survive to reach mature size, clones with many recruitment stems can be considered more successful at regenerating than clones with very few or no recruitment stems.

Winter browsing severity was estimated in each clone by examining about 40 aspen sprouts $(<1 \mathrm{~m})$ or saplings $(1-2 \mathrm{~m})$ per plot that grew closest to quadrant lines laid out in the four cardinal directions. Each aspen sucker was recorded as "browsed" or "unbrowsed" depending on whether the previous year's annual growth had been browsed. Previous year's annual growth was examined for browsing because very little wild ungulate browsing of current year annual growth occurs in summer (Houston 1982). Aspen clones with substantial numbers of sprouts $(<1 \mathrm{~m})$ but no saplings (1$2 \mathrm{~m}$ ) present were assigned the highest index of browse severity. Lack of saplings in an aspen clone strongly suggests suckers are being browsed to the depth of winter snowpack (Romme et al. 1995). Clones with at least one sapling present were scored 0 100 based on the percentage of sprouts and saplings browsed.

Each clone was characterized as occupying a riparian site, upland site, or scree slope. Riparian clones were near a perennial stream in both distance $(<25 \mathrm{~m})$ and elevation $(<10 \mathrm{~m})$; upland clones were not. Each aspen clone was assigned a community type based on its associated vegetation. Aspen-conifer community types contained $\geq 10 \%$ canopy coverage of conifers in the clone (Mueggler 1988).

\section{Data Analyses}

Three hundred forty-one of the 342 clones St. John sampled in 1991 were relocated and sampled in 2006. Twenty-four aspen clones sampled in the study area were cut by beaver or had burned since 1991 and were excluded from analysis. Three additional clones were excluded due to lack of complete data, so the final data set contained information from 315 aspen clones.

St. John (1995) assigned a winter browsing severity score of Low, Medium, or High in each clone, based on the hedging growth form of suckers. In addition to St. John's three categories, we categorized browsing as Very Low for 1991 and 2006 in clones where browsing impacts were low in 1991 and $<10 \%$ of aspen suckers were browsed in winter 20052006. Aspen clones that met these criteria were primarily located on scree slopes. For 2006, we categorized the remaining clones as having Low (10-49\% of suckers browsed), Medium $(50-81 \%$ of suckers browsed), or High $(>81 \%$ of suckers browsed) browsing impacts.

The first objective was to assess the status of aspen recruitment and overstory stem densities across the entire area. A paired $t$-test was used to compare 1991 and 2006 aspen clone density to determine if mean recruitment stems and mean overstory density had changed across the study area. Aspen status in individual drainages $(n=24)$ was categorized by comparing mean recruitment and overstory density in 1991 and 2006. The difference in numbers of aspen clones in the four browse categories in 1991 and 2006 was analyzed with a Pearson's $\chi^{2}$ test. In addition, mean 2006 browse score for each drainage was the explanatory variable and mean 2006 recruitment density was the response variable in a simple regression analysis.

In order to evaluate which covariates might have influenced the changes in recruitment and overstory stems, mixed effects models were fit to log counts of the two responses. Log counts were used because the original counts are right-skewed, and the log transformation gave the residuals a distribution close to normality. If one interprets the model in the original count scale, it is multiplicative rather than additive, inferences are relative to medians rather than means (Ramsey and Shafer 2002), and a null effect of zero in log counts becomes $e^{0}=1$ in the original count scale. The mixed models included fixed effects of browse level (four categories), conifer presence, year, cattle presence, cattle $\times$ year interaction, and random effects for drainage and clone within drainage to account for the repeated measures aspect of the data. Our investigation included elevation, aspect, and site type (scree, riparian, and upland) as additional fixed covariates, but they did not improve the fit for either response ( $P$ values of $0.20,0.09$, and 0.32 , and $0.25,0.18$, and 0.28 for recruits and overstory, respectively). The cattle by year interaction was dropped for the overstory response $(P=0.09)$, and a browse type by year interaction was not needed for the recruitment model $(P=0.57)$. For overstory, a 3-df interaction between browse type and year was not significant $(P=0.16)$, but it did appear that year effect was different for the very low browse type, so a 1-df interaction was used $(P=.018)$ to model this effect. All statistics were computed using R version 2.11.0 (R Development Core Team 2009) and the nlme package (Pinheiro et al. 2010).

\section{RESULTS}

Mean aspen recruitment stem density did not change from 1991 to 2006, while total overstory stems $(>2 \mathrm{~m})$ declined 
Table 1. Mean recruitment stems $(>2 \mathrm{~m}$ tall and $<5 \mathrm{~cm}$ diameter at breast height [dbh]) and all stems $>2 \mathrm{~m}$ densities (SE) for undisturbed aspen clones sampled in 1991 and 2006 on the Northern Yellowstone Winter Range.

\begin{tabular}{lrrrr}
\hline & \multicolumn{2}{c}{ Density } & & \\
\cline { 2 - 3 } & \multicolumn{1}{c}{$1991(n=315) 2006(n=315)$} & $\Delta \%$ & $P$ \\
\hline & ----------- stems ha $^{-1}$---------- & & \\
Recruitment stems $(>2 \mathrm{~m}$ & & & & \\
$\quad$ tall and $<5 \mathrm{~cm}$ dbh) & $467.2(50.3)$ & $463.2(59.4)$ & - & 0.95 \\
Stems $\geq 2 \mathrm{~m}$ (total overstory) & $1257.6(70.1)$ & $1106.3(72.3)$ & $-12 \%$ & 0.04 \\
\hline
\end{tabular}

$12 \%$ (Table 1). Overstory density increased in $30 \%$ of individual clones, was stable in $12 \%$ of clones $(<10 \%$ change), and decreased in $58 \%$ of clones. Examining mean density, $63 \%$ of drainages on the study area lost at least $10 \%$ of their overstory (Table 2). Recruitment stems, however, increased or remained stable in $63 \%$ of drainages. Aspen recruitment and overstory in most $(79 \%$ and $92 \%$, respectively) of our relatively small $\left(\approx 2-10 \mathrm{~km}^{2}\right)$ drainages changed $>10 \%$ over our 15-yr period. The proportion of clones with Medium to High winter browsing impacts declined from 1991 to 2006, while the proportion of clones with Low winter browsing impacts increased $(P=0.001$; Table 3$)$.

Winter ungulate browsing reduced aspen recruitment and total overstory density in 1991 and $2006(P=0.0001)$. Level of browsing was a significant predictor of recruitment and overstory density, with higher levels of browsing reducing aspen density more than lower levels (Tables 4 and 5). Conifer presence in aspen clones reduced recruitment and overstory density in 1991 and $2006(P=0.0001$; Tables 4 and 5). Summer cattle grazing in aspen clones reduced recruitment in $1991(P=0.0001)$, but this effect was not significant in 2006 $(P=0.093$; Table 4$)$. Cattle grazing reduced total aspen overstory density in 1991 and $2006(P=0.022$; Table 5). Clone elevation, aspect, and site type (riparian, upland, or scree) were not included in the final model, as they did not improve the model's predictive power.

After considering the effects of the model covariates, aspen recruitment and overstory density declines from 1991 to 2006 were significant, except that overstory density did not decline where winter ungulate browsing was very low (Tables 4 and 5). The plot of mean aspen recruitment vs. browse category shows that 2006 recruitment was generally slightly lower than 1991 recruitment (Fig. 2), consistent with the Year effect in our model $(P=0.002)$. Mean overstory density appears to have declined more substantially than recruitment density, except

Table 2. Number of drainages $(n=24)$ that lost ${ }^{1}$, had no change $(<-10 \%$ loss or $<10 \%$ gain), or gained aspen recruitment and overstory stems from 1991 to 2006 on the Northern Yellowstone Winter Range.

\begin{tabular}{|c|c|c|c|c|c|c|}
\hline & \multicolumn{2}{|c|}{ Lost } & \multicolumn{2}{|c|}{ No change } & \multicolumn{2}{|c|}{ Gained } \\
\hline & Count & Percent & Count & Percent & Count & Percent \\
\hline Aspen recruitment stems & 9 & 37 & 5 & 21 & 10 & 42 \\
\hline Aspen overstory stems & 15 & 63 & 2 & 8 & 7 & 29 \\
\hline
\end{tabular}

${ }^{1}$ Categorization based on raw means.
Table 3. Number and percentage of aspen clones $(n=315)$ with winter browsing impacts categorized as Very Low, Low, Medium, or High in 1991 and $2006^{1}$ on the Northern Yellowstone Winter Range.

\begin{tabular}{lcccc}
\hline & Very low & Low & Medium & High \\
\hline 1991 & 21 & 42 & 131 & 121 \\
2006 & 21 & 88 & 109 & 97 \\
\hline
\end{tabular}

${ }^{1}$ Distributions differ based on Pearson's $\chi^{2}$ test $(P=0.001)$.

that overstory did not decline where browsing was Very Low (Fig. 2), consistent with the Year $\times$ Browsing interaction in the model $(P=0.018)$.

The largest variance components for aspen recruitment not accounted for by the model came from year-to-year variability within the same clone (69\%; Table 6). Nineteen percent of the variation in recruitment came from clone-to-clone variation within drainages, while $12 \%$ of the variation came from the differences between drainages. Variance components for overstory stem densities were $53 \%$ from clone-to-clone variation within a drainage, $36 \%$ from year-to-year changes within the clone, and $12 \%$ due to differences between drainages (Table 6). Lower winter browsing impacts at the drainage scale are correlated with higher densities of recruitment stems for 2006 at the drainage scale (Fig. 3), especially when drainages with summer cattle grazing are excluded $\left(R^{2}=0.2689 ; P=0.001\right)$. Drainages where cattle grazing ended after 1991 more commonly contained aspen clones with increasing recruitment than drainages where the status of livestock grazing did not change (Fig. 4). Browsing severity in aspen clones on riparian and upland sites was similar in 2006, while browsing was less severe in clones on scree sites (Fig. 5).

\section{DISCUSSION}

\section{Landscape Scale Aspen Sustainability}

Aspen are not recovering on a large scale subsequent to wolf reintroduction on our study area, even though wintering elk numbers declined approximately $45 \%$ from the 1990 s to 2000 2005. Mortality of stems that have grown above $2 \mathrm{~m}$ is greater than recruitment of new stems to this height in the average aspen clone in the study area. Aspen are usually sustainable when new stems are able to grow into the overstory to replace mature stems lost to senescence. The overstory captures most of

Table 4. Estimated fixed effects of aspen recruitment stems (multiplicative scale) from the Northern Yellowstone Winter Range.

\begin{tabular}{lcccc}
\hline & Distribution & Estimate & $\begin{array}{c}95 \% \text { confidence } \\
\text { interval }\end{array}$ & $P$ value \\
\hline Browse & $\mathrm{F}_{3,309}$ & & & 0.0001 \\
$\quad$ Low vs. very low & $\mathrm{t}_{309}$ & 0.386 & $(0.239,0.623)$ & 0.0001 \\
$\quad$ Medium vs. very low & $\mathrm{t}_{309}$ & 0.232 & $(0.145,0.369)$ & 0.0001 \\
$\quad$ High vs. very low & $\mathrm{t}_{309}$ & 0.173 & $(0.108,0.276)$ & 0.0001 \\
Conifers & $\mathrm{t}_{290}$ & 0.601 & $(0.476,0.758)$ & 0.0001 \\
Year & $\mathrm{t}_{309}$ & 0.694 & $(0.554,0.87)$ & 0.002 \\
Cattle $\times$ year & $\mathrm{F}_{1,309}$ & & & 0.025 \\
$\quad 1991$ & $\mathrm{t}_{309}$ & 0.5 & $(0.368,0.679)$ & 0.0001 \\
2006 & $\mathrm{t}_{309}$ & 0.755 & $(0.544,1.048)$ & 0.093 \\
\hline
\end{tabular}


Table 5. Estimated fixed effects of aspen overstory stems (multiplicative scale) from the Northern Yellowstone Winter Range.

\begin{tabular}{lcccc}
\hline & Distribution & Estimate & $\begin{array}{c}95 \% \text { confidence } \\
\text { interval }\end{array}$ & $P$ value \\
\hline Browse & $\mathrm{F}_{3,309}$ & & & 0.0001 \\
Low vs. very low & $\mathrm{t}_{309}$ & 0.679 & $(0.457,1.01)$ & 0.058 \\
Medium vs. very low & $\mathrm{t}_{309}$ & 0.578 & $(0.393,0.851)$ & 0.006 \\
$\quad$ High vs. very low & $\mathrm{t}_{309}$ & 0.521 & $(0.353,0.767)$ & 0.0001 \\
Conifers & $\mathrm{t}_{290}$ & 0.571 & $(0.477,0.684)$ & 0.0001 \\
Cattle & $\mathrm{t}_{309}$ & 0.829 & $(0.707,0.972)$ & 0.022 \\
Year $\times$ browse & $\mathrm{F}_{1,309}$ & & & 0.018 \\
$\quad$ Very low $(<10 \%)$ & $\mathrm{t}_{309}$ & 1.088 & $(0.8,1.479)$ & 0.593 \\
Some $(\geq 10 \%)$ & $\mathrm{t}_{309}$ & 0.74 & $(0.676,0.81)$ & 0.0001 \\
\hline
\end{tabular}

the sunlight and provides the clone with sufficient energy to maintain the roots and stems. If the clone fails to produce enough stems to become part of the overstory, the clone will face a high probability of being replaced by other plant species. About $20 \%$ of aspen overstory stems on the Gallatin National Forest (GNF) portion of the NYWR were established before 1900 (Larsen and Ripple 2003), are nearing the end of their average maximum lifespan of $120 \mathrm{yr}$, and can be expected to deteriorate rapidly (Mueggler 1989). As aging overstory stems die at a faster rate, they must also be replaced with recruitment stems at a faster rate if aspen clones in this study area are to remain stable or increase in density. If new stems grow into the overstory faster than mature stems are lost, aspen can recover or expand on the landscape. This is not presently occurring.
Aspen canopy coverage declined 0.6\% annually from 1958 to 1995 on the GNF portion of the NYWR in the same general area as our study area (Larsen and Ripple 2005). Our 0.8\% annual loss (12\% in $15 \mathrm{yr})$ in overstory density is comparable to Larsen and Ripple's (2005) 0.6\% annual canopy loss. Aspen canopy coverage across the GYE declined 10\% from 1956 to 2001 (Brown et al. 2006). Their approximately $22000 \mathrm{~km}^{2}$ study area included our $560 \mathrm{~km}^{2}$ study area. The $0.2 \%$ average annual aspen decline in the GYE is substantially less than the declines documented by our study and Larsen and Ripple's (2005) study on the NYWR. Our study area was predominantly elk winter range, whereas Brown et al. (2006) included areas with varying degrees of winter elk use in the GYE.

Brown et al. (2006) also categorized aspen overstory in 242 0.81 ha aspen plots as stable $(<10 \%$ change in cover $)$, declining $(>-10 \%$ cover loss), or increasing $(>10 \%$ cover gain). Fifty-nine percent of their plots were categorized as stable, 34\% were declining, and $7 \%$ were increasing. Only $12 \%$ of aspen overstory densities in our smaller 315 plots were stable from 1991 to 2006, while 30\% increased and 58\% declined. On a larger scale, average overstory densities were stable in $8 \%$ of our $2-10 \mathrm{~km}^{2}$ drainages, increased in $29 \%$, and decreased in $63 \%$ of drainages (Table 2). Different plot sizes, different methods (i.e., remote-sensing vs. field sampling), and different parameters being measured (i.e., canopy coverage vs. stem density) likely account for some of the differences between study results. Nevertheless, our large proportions of increasing and decreasing plots may be significant given the fact that elk populations and migration patterns on the NYWR have changed since wolf reintroduction (NYCWWG 2008).

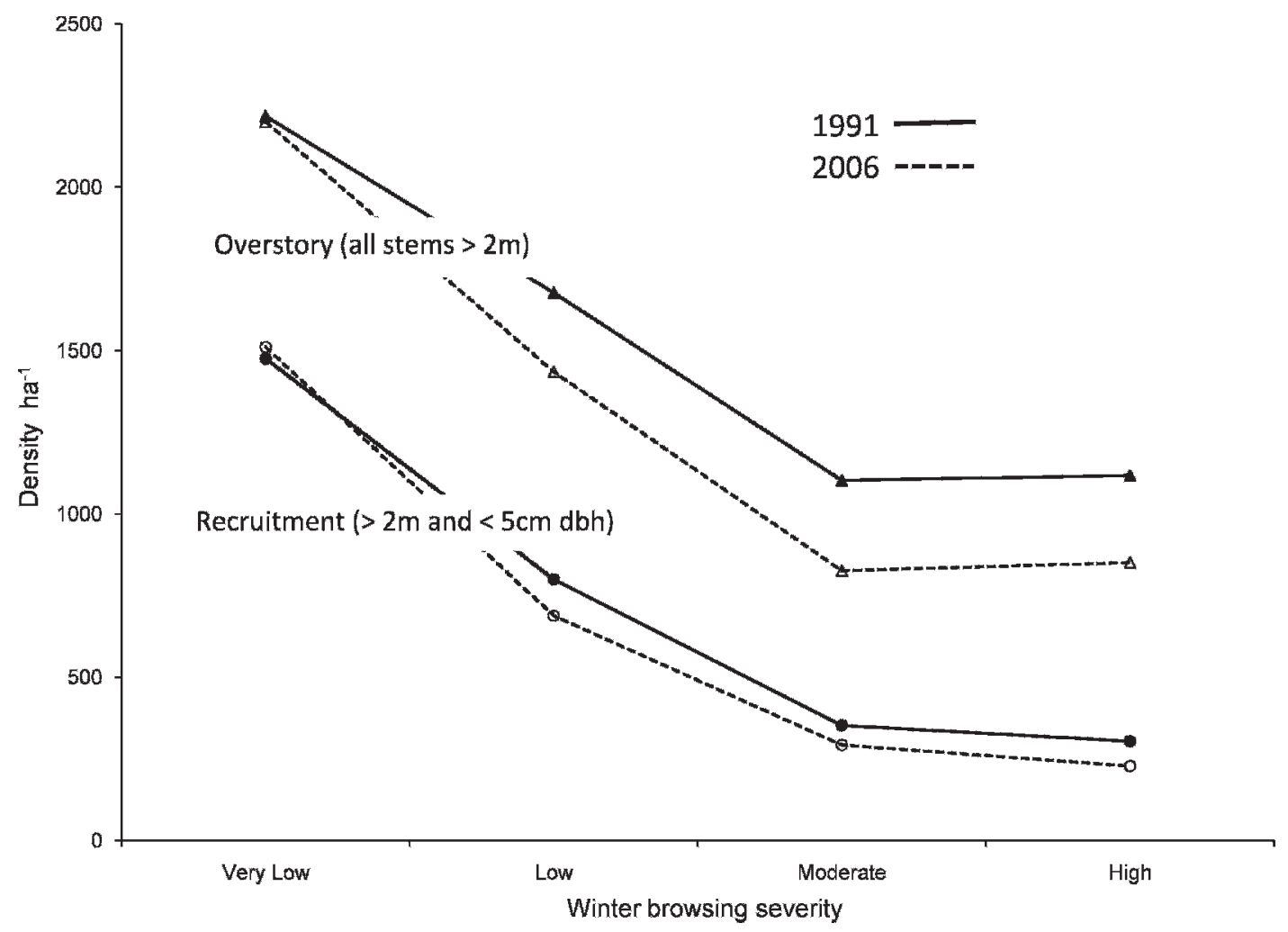

Figure 2. Recruitment (height $>2 \mathrm{~m}$ and diameter at breast height [dbh] $<5 \mathrm{~cm}$ ) and overstory (height $>2 \mathrm{~m}$ ) stem density in 1991 and 2006 in aspen clones with Very Low, Low, Medium, and High winter browsing severity. 
Table 6. Estimated random effects (in log scale) of aspen recruitment stems and overstory stems from drainages, clone to clone within drainage, and year to year variation within a clone from the Northern Yellowstone Winter Range.

\begin{tabular}{lccccccc}
\hline & \multicolumn{3}{c}{ Recruits } & & \multicolumn{2}{c}{ Overstory } \\
\cline { 2 - 3 } \multicolumn{1}{c}{ Level } & Estimated variance & $95 \%$ confidence interval & $\%$ of total variation & & Estimated variance & $95 \%$ confidence interval & $\%$ of total variation \\
\hline Drainage & 0.148 & $(0.058,0.382)$ & $12 \%$ & & 0.083 & $(0.031,0.224)$ & $12 \%$ \\
Clone within drainage & 0.309 & $(0.18,0.53)$ & $19 \%$ & & 0.382 & $(0.304,0.479)$ & $53 \%$ \\
Year to year within clone & 1.056 & $(0.901,1.237)$ & $69 \%$ & & 0.256 & $(0.217,0.298)$ & $36 \%$ \\
\hline
\end{tabular}

\section{Factors Influencing Aspen Regeneration}

Browsing. Ungulate browsing of aspen reduced recruitment and overstory stem densities (Tables 4 and 5). Level of browsing was a significant predictor of recruitment and overstory density, with higher levels of browsing reducing aspen density more than lower levels (Tables 4 and 5). Negative impacts of browsing on aspen regeneration were reported earlier on the NYWR (St. John 1995; NRC 2002) and on other elk winter ranges (Suzuki et al. 1999; White et al. 2003). Aspen clones located on high quality elk winter range with good forage and cover, low human activity, and low snow depths will generally have the highest browsing impacts. The fact that overstory density, as well as more recent recruitment, is reduced where recent browsing is high suggests that preferred elk winter ranges, in general, have not changed. Recruitment stems represent the youngest segment of an aspen clone's overstory, while the total overstory also includes larger, more mature stems that correspond to periods of regeneration in the more distant past.

Overstory density declined from 1991 to 2006, except that overstory density did not decline where browsing impacts were Very Low (Table 5). Our overstory density decline across Low, Medium, and High browsing sites suggests that any browsing above a relatively low level (between $10 \%$ and $50 \%$ of suckers browsed annually) does not allow aspen clones to replace their overstories as quickly as they are dying. However, on Very Low browsing sites where winter ungulate access is mostly precluded by scree slopes or other unique landscape features, recruitment is sufficient such that overstory densities are stable (Table 5; Fig. 2). This suggests that other environmental factors still favor aspen overstory regeneration.

Conifers. The presence of conifers reduced recruitment and overstory stem densities in aspen clones on our study area (Tables 4 and 5). Aspen grow more slowly in the shade of conifers (Shepperd et al. 2001). It is possible that the presence of conifers in an aspen clone is important because they indicate a lack of recent overstory disturbance. In fact, none of the 315 clones' overstories had been disturbed by cutting or fire for at least $15 \mathrm{yr}$ prior to sampling in 2006. Mueggler (1989) estimated that aspen clones in the Intermountain Region with $<1250$ suckers ha ${ }^{-1}$ had "inadequate" sprouting to regenerate clones, while clones with $>2500$ suckers ha ${ }^{-1}$ could likely regenerate aging overstories. Even among the undisturbed clones sampled on our study area, sucker $(<2 \mathrm{~m}$ tall) densities exceeded 2500 suckers $\mathrm{ha}^{-1}$ in $66 \%$ of clones and exceeded 1250 suckers ha ${ }^{-1}$ in $85 \%$ of clones. Furthermore, sucker density in clones on our study area with at least one live stem $>10 \mathrm{~cm}$ dbh averaged 5785 suckers ha ${ }^{-1}$. Ten centimeters dbh

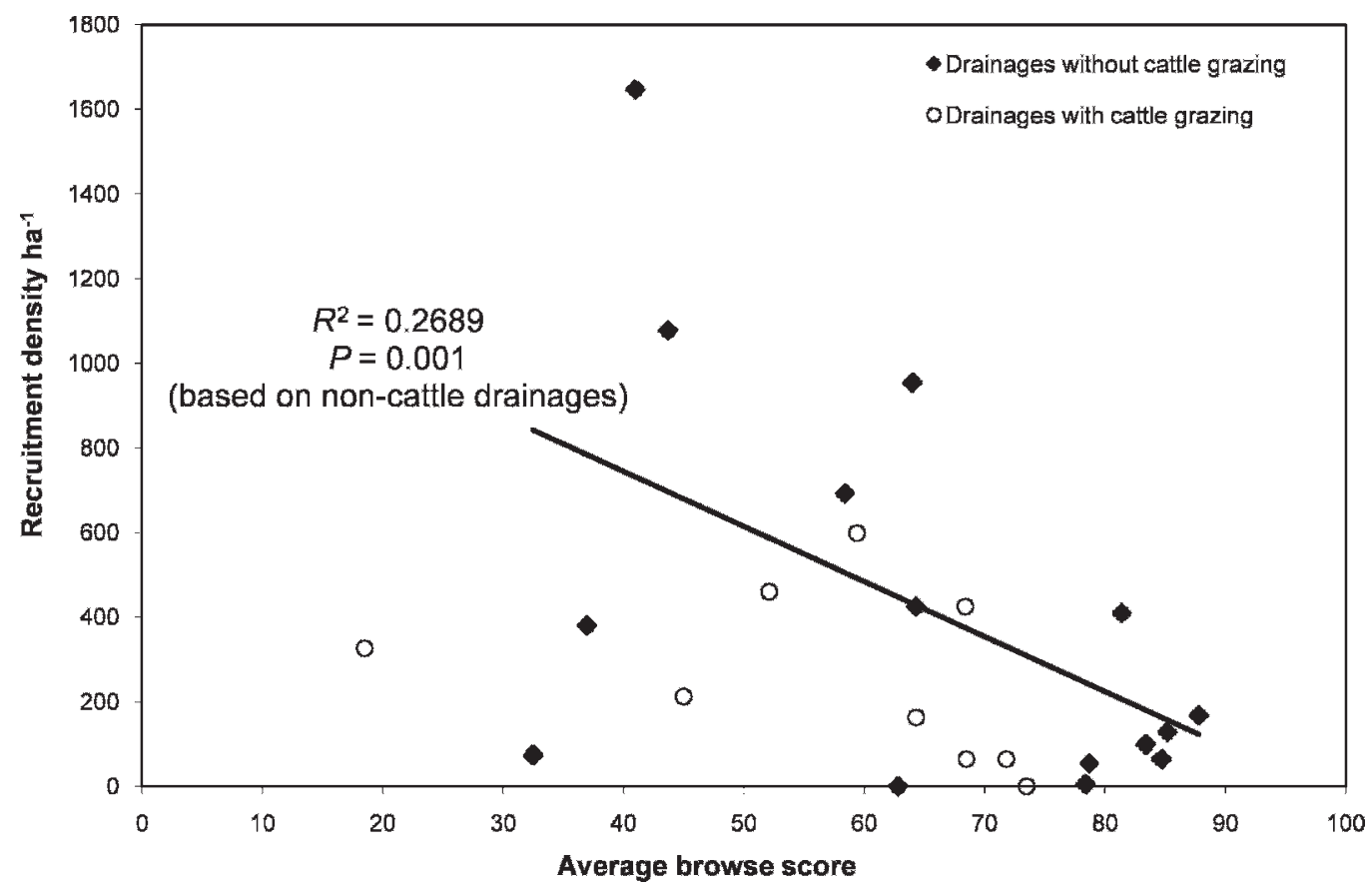

Figure 3. Average aspen recruitment (height $>2 \mathrm{~m}$ and $<5 \mathrm{~cm}$ diameter at breast height [dbh]) stem density and winter browse score in 24 drainages on the Northern Yellowstone Winter Range in 2006. 


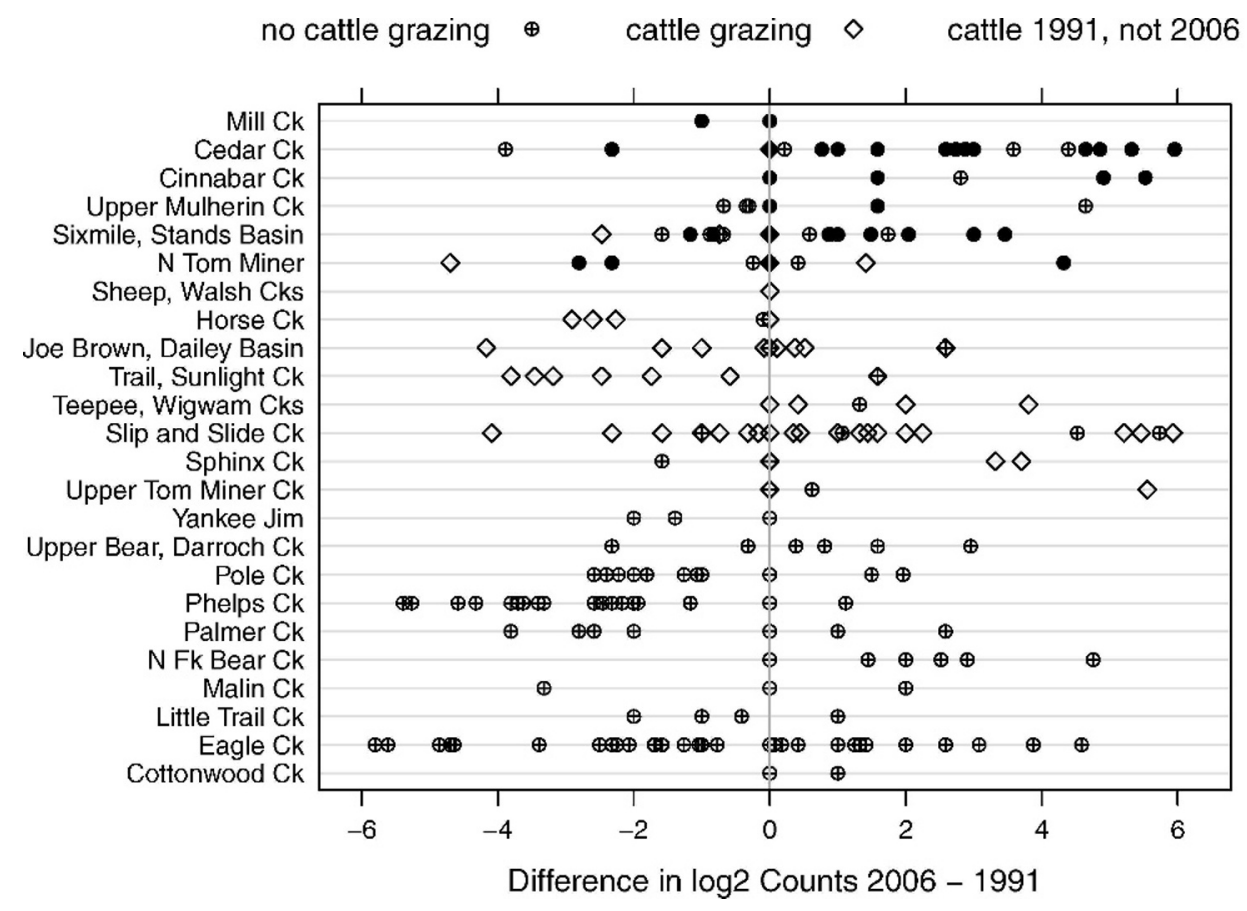

Figure 4. Change in density of aspen recruitment stems (height $>2 \mathrm{~m}$ and diameter at breast height [dbh] $<5 \mathrm{~cm}$ ) from 1991 to 2006 (log $2 \mathrm{scale}$ ) in each clone in 24 drainages on the Northern Yellowstone Winter Range. Symbols indicate whether clones were grazed by cattle (diamonds), not grazed by cattle (circles with +), or grazed in 1991 but not 2006 (solid circles).

aspen stems in this area are approximately $20-28$ yr old (Ripple and Larsen 2000). Clones with mature stems in the overstory generally still sprout substantial numbers of suckers on our study area, so lack of sprouting is likely not a major contributor to aspen decline on this portion of the NYWR. The theory of apical dominance preventing the initiation of root suckers (Schier et al. 1985) does not seem to apply to most clones on our study area and the significant issue related to conifer establishment in aspen clones is probably shading.

Cattle. Summer cattle grazing reduced aspen recruitment stem densities in 1991 (Table 4) and reduced overstory stem densities in 1991 and 2006 (Table 5). Domestic cattle will browse aspen and can suppress aspen growth or prevent clone regeneration (Sampson 1919; Dockrill et al. 2004). Most published negative cattle impacts were from areas with high stocking rates, but cumulative effects of summer cattle browsing and winter wildlife browsing can result in decreased aspen recruitment (St. John 1995; Kay and Bartos 2000). Our Year $\times$ Cattle interaction reflects that allotments containing 61 clones that were grazed by cattle in 1991 were closed to livestock grazing after 1991. These clones were categorized as "no cattle" clones in 2006, but may have had insufficient time to grow recruitment stems in similar densities to clones without cattle grazing for $15+$ yr. Figure 4 displays the changes in recruitment density in each of our 24 drainages, accounting for status of cattle grazing in those drainages. It is notable that recruitment actually increased in most clones where cattle grazing was terminated since 1991, especially in Cedar Creek, Cinnabar Creek, and the Sixmile Creek/Stands Basin area. It appears that in spite of several other important factors influencing aspen recruitment, removal of cattle grazing still had a positive impact on aspen recruitment in many instances.
Climatic or Other Factors. The decline in recruitment across all browse categories (Table 4) suggests that other covariates not included in our model such as a warmer and drier climate (Romme et al. 1995) may play a role in aspen decline. However, other studies suggest that climatic variation probably plays only a minor role in aspen decline on the NYWR. Drought severity and annual precipitation appear unrelated to episodes of aspen regeneration on the NYWR (Larsen and Ripple 2003) and on other GYE elk winter range (Hessl and Graumlich 2002). Warmer temperatures are associated with increased aspen growth in the GYE (Brown et al. 2006). In addition, successful aspen regeneration on xeric scree slopes inaccessible to ungulates (St. John 1995; Larsen and Ripple 2003) and inside all aspen exclosures on the NYWR (Kay 2001) suggest that climate changes have not played a major role in aspen decline.

Closer examination of our data suggests that recruitment declines across all browse classes detected by our model are not biologically important. Because aspen recruitment is episodic and irregular, it is important to also note shifts in mean recruitment. Our model examined shifts in medians. Recruitment may decline in a large proportion of clones, but still remain stable on average for an area if large "flushes" of growth can compensate for loss in stems nearby. This appears to have occurred on our study area from 1991 to 2006, as mean recruitment did not decline (Table 1). Our plots of recruitment density and browse categories also demonstrate that recruitment declines from 1991 to 2006 were relatively minor compared to overstory declines (Fig. 2). And although recruitment declined in clones with very low browsing (Table 4), recruitment was still sufficient to replace existing overstories (Table 5). This gives further credence to our supposition that the Year effect in our model for recruitment is not biologically 
Scree
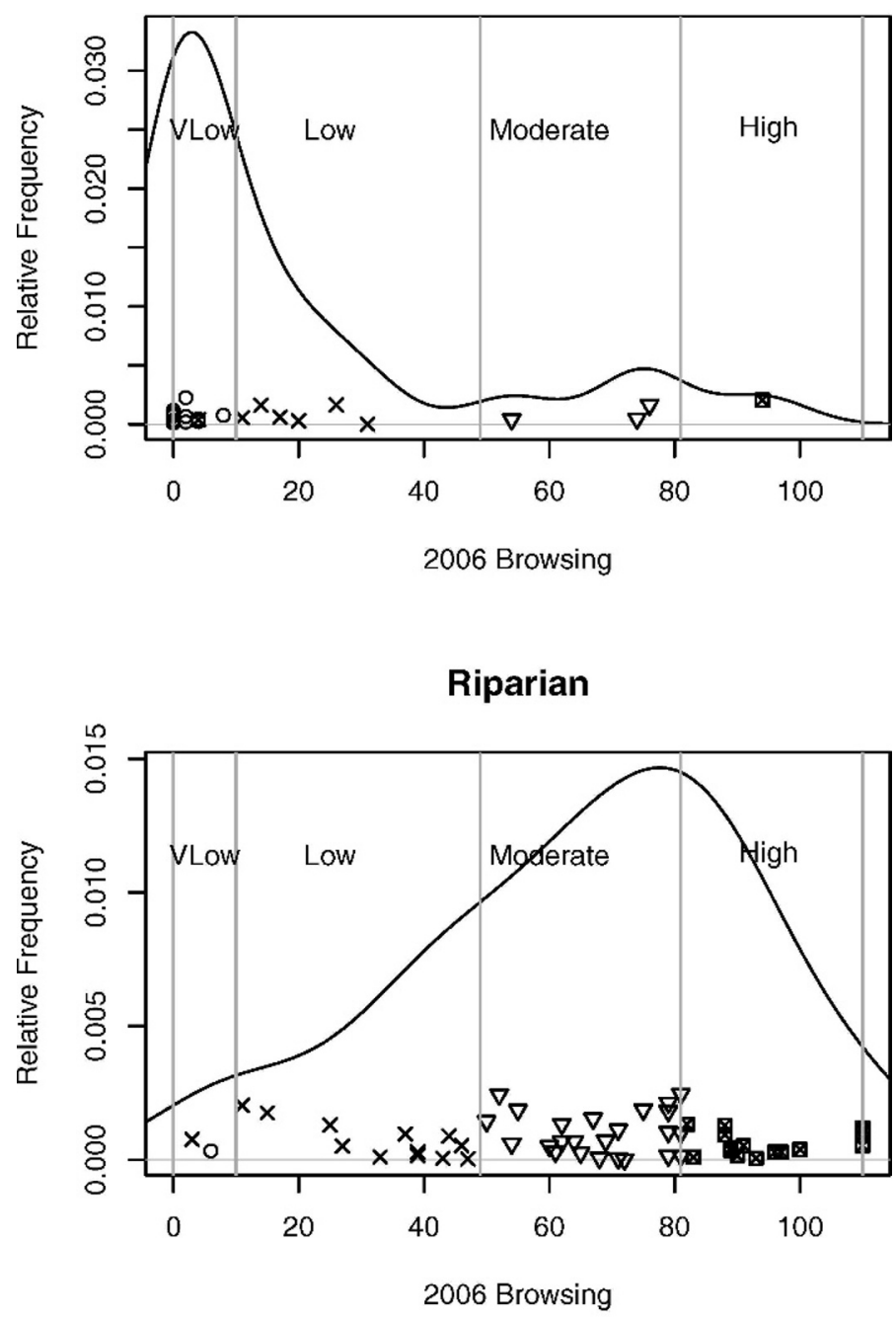

Upland

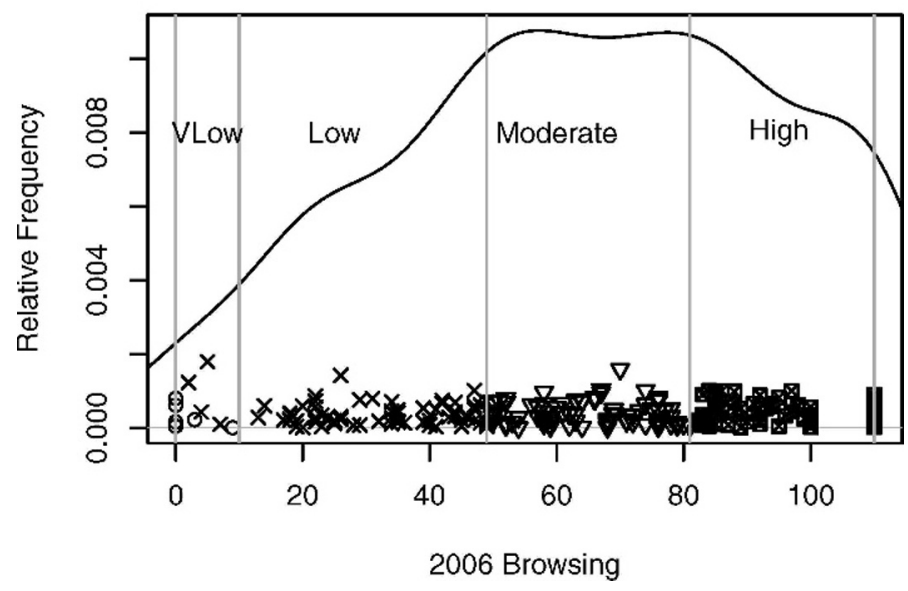

Figure 5. Winter ungulate browsing severity in aspen clones in 2006 at scree, riparian, and upland sites on the Northern Yellowstone Winter Range. important. The ecology of aspen is such that recruitment will fluctuate widely. A decline in recruitment is biologically important when total overstory is declining, which only occurred where browsing exceeded very low levels (Table 5).

Variance Components. Most of the variation in aspen density not accounted for by our model came from year-to-year variability within the same clone, especially for recruitment (Table 6). The inherent spatial and temporal variability of aspen recruitment within a clone probably accounts for much of this variability. A weakness of our circular plots is that they often do not encompass most of an aspen clone. Even for sustainable aspen clones, it is typical for some parts of the clone to have abundant recruitment while other parts have none (Bartos 2001). These areas could shift over time due to selfthinning where recruitment is dense or new recruitment where mature stems have recently senesced. Another weakness of our model and possible source of variability is the fact that our categories of browse severity did not account for overstory mortality caused by bark stripping and antler rubbing (Keigley and Frisina 2005). Our observations were that this was not a major factor on our study area in 2006, but it is possible that some of our year-to-year variance could have been assigned to these ungulate impacts if we had accounted for them.

Two smaller additional sources of variation in recruitment and overstory came from 1) clone-to-clone variation within drainages and 2) differences between drainages (Table 6). For overstories, these sources of variation combined accounted for $47 \%$ of the total variation. We propose these sources of variation could be ascribed to factors that are quite static, such as snow catchment areas, springs, areas with especially dense conifer canopy, or traditional elk wintering areas and cattle loafing sites. Although we accounted for winter browsing, conifer establishment, and cattle grazing in our model, these factors could still be sources of variation because of the nature of the data we incorporated into the model. We only included winter browsing data from 1991 and 2006, so long-term, traditional elk use of drainages or specific sites within drainages may have been underrepresented. Similarly, the level of conifer establishment or level of cattle use at each clone or in each drainage was not accounted for; our data merely indicated whether or not conifers or cattle were present in each year. On a clone-to-clone basis, springs or snow catchment areas could create favorable environmental conditions that change very little over time; this would be most represented by overstory clone-to-clone variation not described by our model, which accounted for $36 \%$ of total variation (Table 6). Recent data for the NYWR indicate that aspen sucker survival is closely correlated with mature stem growth (Kauffman et al. 2010), further evidence that site conditions play an important role in the developing density of the clone.

Clone-to-clone variation within drainages and differences between drainages only accounted for $30 \%$ of the total variation in recruitment (Table 6). The effects were mostly overpowered by the inherent variability of recruitment. Besides this inherent variability, elk populations have been quite dynamic on our study area since 1991. For example, large numbers of elk died in the severe winter of 1996-1997 and wolf packs have become established in several of our drainages since 2000. Because we did not measure browsing repeatedly 
throughout our 15-yr period, some of these browsing effects may have been detected as year-to-year clone variability by our model. The drainage effect on recruitment ( $10 \%$ of variation) was probably minor for our model because we measured "snapshots" of recruitment and browsing in 1991 and 2006, but analyzed changes that occurred over a 15 -yr period.

A different way to look at our data is to examine current recruitment and browsing in 2006, averaged for each of our 24 drainages (Fig. 3). Winter browsing severity and recruitment density are correlated $\left(R^{2}=0.27 ; P=0.001\right)$. This suggests higher recruitment densities are associated with drainages that are currently less attractive to elk than others. However, the correlation is not strong because other factors besides elk browsing play a role, as evidenced by our model. The correlation is weaker still in drainages where cattle graze because our winter browsing index is not sensitive to summer cattle browsing.

\section{Landscape Scale and Small Scale Trophic Cascades}

Aspen recruitment density and total overstory density on the $40 \%$ of the NYWR that we studied has not increased since wolf reintroduction. Our study did not examine aspen on the NYWR inside YNP, but our results do not support suppositions that aspen had begun a large-scale recovery on the NYWR inside YNP by 2006, as elk numbers had only declined $20 \%$ inside YNP, but declined $45 \%$ over the same time period on our study area. Also, a recent study of 16 clones across the NYWR inside YNP indicated that aspen are not recruiting new stems above $2 \mathrm{~m}$ (Kauffman et al. 2010). Despite the $45 \%$ reduction in elk on our study area, we believe that browsing was still too high in 2006 for aspen to respond at the landscape scale $\left(560 \mathrm{~km}^{2}\right)$ or that not enough time had passed for significantly more aspen suckers to grow above $2 \mathrm{~m}$ since elk populations declined. Other factors not influenced by wolves also suppress aspen regeneration, but we still believe elk browsing is the most important factor.

While aspen recruitment and overstory has not increased at the landscape scale $\left(560 \mathrm{~km}^{2}\right)$, mean density has increased in some of our $2-10 \mathrm{~km}^{2}$ drainages (Table 2). For example, recruitment density quadrupled in the $4.3 \mathrm{~km}^{2}$ North Fork of Bear Creek drainage. The North Fork of Bear Creek was a known area of high wolf activity (Doug Smith, personal communication, June 2007), and browsing levels were consistently low throughout the drainage. Similarly, riparian aspen clones in an approximately $4.5 \mathrm{~km}^{2}$ study area of the Lamar Valley on the NYWR inside YNP are exhibiting signs of reduced browsing and increased growth since 2000 (Ripple and Beschta 2007). Smaller scale increases in cottonwood and willow heights since wolf reintroduction have also been documented in northern YNP (Ripple and Beschta 2003, 2004). However, given the results of our study, it is doubtful that these localized aspen, willow, and cottonwood height increases should be extrapolated to the entire NYWR. Smallscale evidence can support or fail to support the hypothesis that aspen recruitment has increased, depending on the area studied. Localized new growth of woody plants gives reason for optimism that these plants can sustain themselves, but it is also important to note how local recruitment increases affect overstory replacement on the landscape scale.
Researchers have proposed that the risk of wolf predation has redistributed elk away from riparian areas on the NYWR (Beyer et al. 2007; Ripple and Beschta 2007). Our investigation included site type (upland, riparian, or scree) in our model, but it did not improve our model's predictive power $(P=0.30)$. Apart from scree sites that obviously exclude most ungulates, browsing patterns in upland and riparian aspen clones were similar (Fig. 5). Earlier research indicated that increased riparian aspen growth relative to upland aspen only occurred in areas where wolf use was high (Ripple et al. 2001). Density of known wolves was about $35 \%$ lower on our study area in 2000-2005 than on the NYWR inside YNP, so wolf density outside YNP could be below the threshold at which nonlethal wolf effects on elk behavior and aspen recruitment can be detected. Alternatively, elk on the NYWR may actually be consuming similar or greater amounts of aspen in riparian areas when wolves are present, as occurred with willows on the Gallatin winter range (Creel and Christianson 2009). If the latter is true, instances of increased riparian aspen recruitment relative to upland aspen, i.e., the Lamar Valley (Ripple and Beschta 2007), may not have occurred across multiple riparian sites on the NYWR.

If they are to occur, we propose that wolf-caused improvements in aspen recruitment on our portion of the NYWR will first occur at sites or drainages that are marginally attractive wintering areas for elk. A smaller northern Yellowstone elk herd may not need to utilize areas of high wolf activity, high snow depths, high human activities, or low forage and cover availability. These areas may not necessarily be sites where predation risk is elevated (i.e., riparian areas vs. uplands), but may be sites that have been historically less attractive to elk than prime wintering areas. The proportion of clones with medium or high browsing impacts declined from 1991 to 2006 on our study area, while the proportion with low browsing impacts increased (Table 3). This could be an indication that elk browsing impacts on aspen have been reduced since 1991. However, these results should be viewed with caution since our methods of assessing browsing in 1991 and 2006 were not identical and because any browsing reductions have not yet translated into recruitment. Recruitment response in individual clones to reduced elk use will be difficult to detect because of inherent year-to-year variability in recruitment and other important covariates besides elk browsing such as conifers and cattle. These effects may be somewhat abated if intermediate-sized areas are studied. In fact, aspen recruitment has increased in some individual drainages on our study area (Table 2; Fig. 4). However, results from even intermediatesized drainages should not be extrapolated to the landscape, as recruitment increases in some parts of our study area have not compensated for continued declines elsewhere.

More time for aspen growth and continued elk population declines since the completion of this study may result in aspen recruitment increases in other nonpreferred elk wintering areas on the NYWR. Elk numbers on the NYWR in 2005 were approximately 9500 , but have since declined to approximately 6500 in 2007-2010 (NYCWWG 2010). Elk numbers on the NYWR north of YNP have decreased only slightly since 2006, but have declined significantly since 2006 on the NYWR inside YNP due to a greater proportion of elk migrating out of YNP in winter (NYCWWG 2008). If this pattern continues, aspen 
clones inside YNP could begin to recruit more stems above elk browsing height. Large-scale disturbance promoted prolific aspen root suckering when elk numbers were high after the 1988 fires, but did not regenerate the aspen overstory (Romme et al. 1995). Beaver cutting in the Eagle Creek drainage on our study area has not regenerated aspen overstory (Kimble 2007; McColley 2007). However, future large-scale disturbance of aspen could result in overstory regeneration if high numbers of root sprouts can overwhelm today's smaller elk herd's propensity to suppress the growth of aspen above browsing height. Patterns of elk browsing in aspen clones on our study area could also change if wolf pack distribution changes. If more wolf packs are permanently established north of YNP, elk could redistribute away from high-risk predation sites (Ripple and Beschta 2003, 2006, 2007), although it is questionable at what spatial scale this might occur (Kauffman et al. 2010). By the parameters measured in this study, a wolf-elk-aspen trophic cascade resulting in a recovery in aspen overstory is not yet occurring consistently across this portion of the NYWR.

\section{IMPLICATIONS}

With current elk populations, it appears that aspen overstory will continue to decline on the NYWR outside YNP. Aspen are recovering in some areas, but not at the landscape scale on our study area. Elk continue to browse aspen in preferred wintering areas and recent recruitment of new aspen overstory stems is not sufficient to replace dying stems. The ultimate ability of aspen to sustain current overstory densities on the NYWR will likely depend on whether the aspen recruitment increases in some areas are able to compensate for continued heavy elk browsing and continued aspen decline in preferred wintering areas. Future study should continue to focus on landscape scale monitoring of aspen clone conditions across many drainages if researchers wish to detect meaningful aspen recovery on the NYWR.

\section{ACKNOWLEDGMENTS}

Rob St. John provided early guidance and completed the critically important 1991 aspen survey. Karen Kimble faithfully assisted with most of the fieldwork, while Heidi Bergsjo, Ken Britton, Kasper Engelhardt, Kat Hickman, Gidske Houge, Matt Latini, Sam McColley, Leah Spurlin, Kristine Ulvund, Sarah Wallace, and Jeremy Zimmer provided excellent additional field help. Special thanks to the private ranches that provided access through their land to access isolated Forest Service parcels. We are grateful to Harrie Sherwood for assisting with statistical analysis and Lynn Irby, Jeremy Zimmer, Tyler May, and two anonymous peers for reviewing and improving this manuscript.

\section{LITERATURE CITED}

Bartos, D. L. 2001. Landscape dynamics of aspen and conifer forests. In: W. D. Shepperd, D. Binkley, D. L. Bartos, T. J. Stohlgren, and L. G. Eskew [EDS.], Sustaining aspen in western landscapes: symposium proceedings; 1315 June 2000; Grand Junction, CO, USA. Proceedings RMRS-P-18. Fort Collins, CO, USA: US Department of Agriculture, Forest Service, Rocky Mountain Research Station. $460 \mathrm{p}$.

Bartos, D. L., J. K. Brown, and G. D. Booth. 1994. Twelve year's biomass response in aspen communities following fire. Journal of Range Management 47:79-83.
Beyer, H. L., E. H. Merrill, N. Varley, and M. S. Boyce. 2007. Willow on Yellowstone's Northern Range: evidence for a trophic cascade? Ecological Applications 17:1563-1571.

Brown, K., A. J. Hansen, R. E. Keane, and L. J. Graumlich. 2006. Complex interactions shaping aspen dynamics in the Greater Yellowstone Ecosystem. Landscape Ecology 21:933-951.

Creel, S., and D. Christianson. 2009. Wolf presence and increased consumption by Yellowstone elk: implications for trophic cascades. Ecology 90:2454-2466.

Debyle, N. V. 1985a. Wildlife. In: N. V. Debyle and R. P. Winokur [eds.]. Aspen: ecology and management in the western United States. Fort Collins, CO, USA: US Department of Agriculture, Forest Service, Rocky Mountain Forest and Range Experiment Station General Technical Report RM-119. 283 p.

Debyle, N. V. 1985b. Animal impacts. In: N. V. Debyle and R. P. Winokur [eds.]. Aspen: ecology and management in the western United States. Fort Collins, CO, USA: US Department of Agriculture, Forest Service, Rocky Mountain Forest and Range Experiment Station General Technical Report RM-119. 283 p.

Despain, D. G., D. B. Houston, M. Meagher, and P. Schullery. 1986. Wildlife in transition-man and nature on Yellowstone's northern range. Boulder, CO, USA: Roberts Rinehart, Inc. 142 p.

Dockrill, C. V. M., P. V. Blenis, A. W. Bailey, And J. R. King. 2004. Effect of summer cattle grazing on aspen stem injury, mortality and growth. Forestry Chronicle 80:257-261.

Fortin, D. F., H. L. Beyer, M. S. Boyce, D. W. Smith, T. Duchesne, and J. S. Mao. 2005. Wolves influence elk movement: behavior shapes a trophic cascade in Yellowstone National Park. Ecology 86:1320-1330.

Frey, B. R., V. J. Lieffers, S. M. Landhausser, P. G. Comeau, and K. J. Greenway. 2003. An analysis of sucker regeneration of trembling aspen. Canadian Journal of Forest Research 33:1169-1179.

Hessl, A. E., and L. J. Graumlich. 2002. Interactive effects of human activities, herbivory, and fire on quaking aspen (Populus tremuloides) age structures in western Wyoming. Journal of Biogeography 29:889-902.

Houston, D. B. 1982. The Northern Yellowstone elk: ecology and management. New York, NY, USA: Macmillan. $474 \mathrm{p}$.

Kauffman, M. J., J. F. Brodie, and E. S. Jules. 2010. Are wolves saving Yellowstone's aspen? A landscape-level test of a behaviorally mediated trophic cascade. Ecology 91:2742-2755.

KaY, C. E. 1985. Aspen reproduction in the Yellowstone Park-Jackson Hole area and its relationship to the natural regulation of ungulates. In: G. W. Workman [ED.]. Western elk management: a symposium. Logan, UT, USA: Utah State University. $213 \mathrm{p}$.

KAY, C. E. 1990. Yellowstone's northern elk herd: a critical evaluation of the "natural regulation" paradigm [dissertation]. Logan, UT, USA: Utah State University. 490 p.

KAY, C. E. 2001. Long-term aspen exclosures in the Yellowstone ecosystem. In: W. D. Shepperd, D. Binkley, D. L. Bartos, T. J. Stohlgren, and L. G. Eskew [EDS.], Sustaining aspen in western landscapes: symposium proceedings; 1315 June 2000; Grand Junction, CO, USA. Proceedings RMRS-P-18. Fort Collins, CO, USA: US Department of Agriculture, Forest Service, Rocky Mountain Research Station. $460 \mathrm{p}$.

KaY, C. E., AND D. L. BaRTos. 2000. Ungulate herbivory on Utah aspen: assessment of long term exclosures. Journal of Range Management 53:145-153.

KeIgley, R. B., AND M. R. Frisina. 2005. Aspen height, stem-girth and survivorship in an area of high ungulate use. In: M. R. Frisina and S. J. Knapp [EDS.]. Statewide browse evaluation project report no. 2. Helena, MT, USA: Montana Fish, Wildlife, and Parks. $110 \mathrm{p}$.

KImBLE, D. S. 2007. Quaking aspen ecology on Forest Service lands north of Yellowstone National Park [thesis]. Bozeman, MT, USA: Montana State University. $79 \mathrm{p}$.

Larsen, E. J., and W. J. Ripple. 2003. Aspen age structure in the northern Yellowstone ecosystem, USA. Forest Ecology and Management 179:469-482.

LARSEN, E. J., AND W. J. RipPLE. 2005. Aspen stand conditions on elk winter ranges in the northern Yellowstone ecosystem, USA. Natural Areas Journal 25:326-338.

Laundre, J. W., L. Hernandez, and K. B. Altendorf. 2001. Wolves, elk, and bison: reestablishing the "landscape of fear" in Yellowstone National Park, U.S.A. Canadian Journal of Zoology 79:1401-1409. 
Mao, J. S., M. S. Boyce, D. W. Smith, F. J. Singer, D. J. Vales, J. M. Vore, and E. H. MerRiLl. 2005. Habitat selection by elk before and after wolf reintroduction in Yellowstone National Park. Journal of Wildlife Management 69:1691-1707.

McColley, S. D. 2007. Restoring aspen riparian stands with beaver on the Northern Yellowstone Winter Range [thesis]. Bozeman, MT, USA: Montana State University. $67 \mathrm{p}$.

McDonough, W. T. 1985. Sexual reproduction, seeds, and seedlings. In: N. V. Debyle and R. P. Winokur [EDs.]. Aspen: ecology and management in the western United States. Fort Collins, CO, USA: US Department of Agriculture, Forest Service, Rocky Mountain Forest and Range Experiment Station General Technical Report RM-119. 283 p.

Muegglek, W. F. 1988. Aspen community types of the Intermountain Region. Ogden, UT, USA: US Department of Agriculture, Forest Service, Intermountain Forest and Range Research Station General Technical Report INT-250. 135 p.

Mueggler, W. F. 1989. Age distribution and reproduction of intermountain aspen stands. Western Journal of Applied Forestry 4:41-45.

[NRC] National Research Council. 2002. Ecological dynamics on Yellowstone's northern range. Washington, DC, USA: National Academies Press. $180 \mathrm{p}$.

[NYCWWG] Northern Yellowstone Cooperative Wildiffe Working Group. 2005. 2005 Annual Report. Available at: http://fedgycc.org/documents/2005_NYCWWG_ FnIRpt.pdf. Accessed 20 March 2006.

NYCWWG. 2008. Yellowstone National Park news release: 2007-2008 winter count of northern Yellowstone elk. Available at: http://nps.gov/yell/press/ parknews/08010.htm. Accessed 3 April 2008.

NYCWWG. 2010. Yellowstone National Park news release: winter count shows northern elk herd numbers remain stable. Available at: http://nps.gov/yell/ press/parknews/10016.htm. Accessed 26 March 2010.

Pinheiro, J., D. Bates, S. Debroy, and D. Sarkar R Development Core Team. 2010. nIme: Linear and Nonlinear Mixed Effects Models version 3.1-97. Available at: http://cran.r-project.org/web/packages/nlme/nlme.pdf. Accessed 1 May 2010.

R Development Core Team. 2009. R: a language and environment for statistical computing. R Foundation for Statistical Computing. Available at: http://www. R-project.org. Accessed 1 May 2010.

Ramsey, F. L., and D. W. Shafer. 2002. The statistical sleuth. Pacific Grove, CA, USA: Duxbury Press. $742 \mathrm{p}$.

RIPPLE, W. J., AND R. L. BESCHTA. 2003. Wolf reintroduction, predation risk, and cottonwood recovery in Yellowstone National Park. Forest Ecology and Management 184:299-313.

Ripple, W. J., AND R. L. BesCHTA. 2004. Wolves, elk, willows, and trophic cascades in the upper Gallatin Range of southwestern Montana, USA. Forest Ecology and Management 200:161-181.

RiPPLE, W. J., AND R. L. BESCHTA. 2006. Linking wolves to willows via risk-sensitive foraging by ungulates in the northern Yellowstone ecosystem. Forest Ecology and Management 230:96-106.

RIPPLE, W. J., AND R. L. BESCHTA. 2007. Restoring Yellowstone's aspen with wolves. Biological Conservation 138:514-519.

RipPle, W. J., AND E. J. LARSEN. 2000. Historic aspen recruitment, elk, and wolves in northern Yellowstone National Park, USA. Biological Conservation 95:361-370.

Ripple, W. J., E. J. Larsen, R. A. Renkin, and D. W. Smith. 2001. Trophic cascades among wolves, elk, and aspen on Yellowstone National Park's northern range. Biological Conservation 102:227-234.

Romme, W. H., M. G. Turner, L. L. Wallace, and J. S. Walker. 1995. Aspen, elk, and fire in northern Yellowstone National Park. Ecology 76:2097-2106.
Sampson, A. W. 1919. Effect of grazing upon aspen reproduction. Professional Paper Bulletin No. 471. Washington, DC, USA: US Department of Agriculture, Forest Service. $27 \mathrm{p}$.

SchieR, G. A., J. R. Jones, and R. P. WinokUR. 1985. Vegetative Regeneration. In: N. V. Debyle and R. P. Winokur [EDs.]. Aspen: ecology and management in the western United States. General Technical Report RM-119. Fort Collins, C0, USA: US Department of Agriculture, Forest Service, Rocky Mountain Forest and Range Experiment Station. 283 p.

Shepperd, W. D., D. L. Bartos, and S. A. Mata. 2001. Above- and below-ground effects of aspen clonal regeneration and succession to conifers. Canadian Journal of Forest Research 31:739-745.

Smith, D. W., D. R. Stahler, and D. S. Guernsey. 2005. Yellowstone Wolf Project: annual report, 2004. Yellowstone Center for Resources YCR-2005-02. Yellowstone National Park, WY, USA: US Department of Interior, National Park Service, Yellowstone Center for Resources. $18 p$.

St. JoHN, R. A. 1995. Aspen stand recruitment and ungulate impacts: Gardiner Ranger District, Gardiner, Montana [thesis]. Missoula, MT, USA: The University of Montana. $92 \mathrm{p}$.

Suzuki, K., H. Suzuki, D. Binkley, and T. J. Stohlgren. 1999. Aspen regeneration in the Colorado Front Range: differences at local and landscape scales. Landscape Ecology 14:231-237.

[USFWS] US Fish and Wildlife Service, Nez Perce Tribe, National Park Service, Montana Fish, Wildlife and Parks, Idaho Fish and Game, and USDA Wildlife Services. 2005. Rocky Mountain Wolf Recovery 2004 Annual Report. D. Boyd [ED.]. Helena, MT, USA: US Fish and Wildlife Service, Ecological Services. $72 \mathrm{p}$.

usfws, Nez Perce Tribe, National Park Service, Montana Fish, Wildlife and Parks, Idaho Fish and Game, and USDA Wildlife Services. 2006. Rocky Mountain Wolf Recovery 2005 Annual Report. C. A. Sime and E. E. Bangs [EDS.]. Helena, MT, USA: US Fish and Wildlife Service, Ecological Services. $130 \mathrm{p}$.

usfWS, Nez Perce Tribe, National Park Service, and USDA Wildlife Services. 2001, Rocky Mountain Wolf Recovery 2000 Annual Report. Helena, MT, USA: US Fish and Wildlife Service, Ecological Services. $35 \mathrm{p}$.

uSfWS, Nez Perce Tribe, National Park Service, and USDA Wildlife Services. 2002. Rocky Mountain Wolf Recovery 2001 Annual Report. T. Meier [ED.]. Helena, MT, USA: US Fish and Wildlife Service, Ecological Services. 43 p.

USFWS, Nez Perce Tribe, National Park Service, and USDA Wildlife Services. 2003. Rocky Mountain Wolf Recovery 2002 Annual Report. T. Meier [ED.]. Helena, MT, USA: US Fish and Wildlife Service, Ecological Services. 64 p.

USFWS, Nez Perce Tribe, National Park Service, and USDA Wildlife Services. 2004. Rocky Mountain Wolf Recovery 2003 Annual Report. T. Meier [ED.]. Helena, MT, USA: US Fish and Wildlife Service, Ecological Services. 65 p.

Vucetich, J. A., D. W. Smith, and D. R. Stahler. 2005. Influence of harvest, climate, and wolf predation on Yellowstone elk, 1961-2004. Oikos 111:259-270.

WAGNER, F. H. 2006. Yellowstone's destabilized ecosystem: elk effects, science, and policy conflict. New York, NY, USA: Oxford University Press. $371 \mathrm{p}$.

Western Regional Climate Center. 2007. Gardiner, MT and Jardine, MT climate summaries. Available at: http://www.wrcc.dri.edu/summary/climsmmt.html. Accessed 17 January 2007.

White, C. A., M. C. Feller, and S. Bayley. 2003. Predation risk and the functional response of elk-aspen herbivory. Forest Ecology and Management 181:77-97.

[YNP] Yellowstone National Park. 1997. Yellowstone's northern range: complexity and change in a wildland ecosystem. Mammoth Hot Springs, WY, USA: National Park Service. 